\title{
The frailty syndrome in older adults with type 2 diabetes mellitus and associated factors
}

\author{
Bartolomeu Fagundes de Lima Filho' ${ }^{\mathbb{D}}$ \\ Antônia Gilvanete Duarte Gamal (ID \\ Vanessa da Nóbrega Dias' (ID \\ Eliza Mikaele Tavares da Silva² ${ }^{\mathbb{D}}$ \\ Fabricia Azevedo da Costa Cavalcanti ${ }^{1}$ (D) \\ Juliana Maria Gazzola' (1D
}

\section{Abstract}

Objective: To compare clinical-functional factors among groups in relation to the frailty syndrome (pre-frail and frail) phenotype profile in older adults with type 2 diabetes mellitus (DM 2). Methods: A descriptive, analytical, cross-sectional study with a quantitative approach was performed. A total of 113 diabetic older adults of both sexes were evaluated in terms of their personal, socio-demographic, clinical-functional, mental, cognitive and fragility phenotype data. The Chi-square test and a logistic regression model were used. Results: The mean age was $68.66 \pm 6.62$ years, and the sample was mostly female $(61.9 \%)$, illiterate or with an incomplete primary education $(60.2 \%)$, pre-frail $(52.2 \%)$, sedentary (79.6\%), and had been diagnosed with DM2 for more than 5 years $(58.3 \%)$. There was a significant association between "pre-frail and frail" individuals and schooling ( $p=0.004)$, social participation $(p=0.004)$, a subjective perception of vision $(p=0.004)$, glycated hemoglobin $(p=0.036)$, limb pain $(p=0.012)$, depressive symptoms $(p=0.002)$ and mobility ( $p=0.004)$. The logistic regression model showed an accuracy of $93.6 \%$ and the significant variables were education $(p=0.039)$, pain in the lower limbs $(p=0.025)$ and risk of falls $(p=0.033)$. Conclusion: among all the factors related to the "pre-frail" and "frail" phenotype, schooling, pain in the lower limbs and mobility were most related to the worsening of the syndrome and its progress.

\footnotetext{
1 Universidade Federal do Rio Grande do Norte (UFRN), Programa de Pós-Graduação em Fisioterapia, Departamento de Fisioterapia, Natal, RN, Brasil.

2 Universidade Federal do Rio Grande do Norte (UFRN), Programa de Pós-Graduação em Fonoaudiologia, Departamento de Fonoaudiologia, Natal, RN, Brasil.
}

Funding: The present study was financed in part by the Coordination for the Improvement of Higher Education Personnel (Coordenação de Aperfeiçoamento de Pessoal de Nível Superior - Brasil or CAPES) - Financial Code 001.

The authors declare there are no conflicts of interest in relation to the present study.

Correspondence

Bartolomeu Fagundes de Lima Filho

Keywords: Health of the Elderly. Frailty . Diabetes Mellitus, Type 2. 


\section{INTRODUCTION}

The Frailty Syndrome (FS) among older adults is a complex condition leading to a decline in the body's homeostatic reserve capacity and also in the resistance of stressors ${ }^{1}$. In this sense, the alterations in the body of a frail older adult generate a gradual decline in all biological systems in a pathological manner, causing vulnerability and varied clinical problems ${ }^{2}$.

There are many consequences of the emergence of the FS in this population, since its characteristics encompass all organic systems and cause globalized damage to the body of the older adult ${ }^{3}$. Among these consequences, the decrease in homeostatic reserves stands out. In this context, sarcopenia (loss of muscle mass) has a significant influence on FS and is directly associated with other chronic diseases, such as type 2 Diabetes Mellitus (DM2) ${ }^{4}$.

DM2 is a metabolic disease evidenced by blood hyperglycemia, which negatively affects the cardiac, visual, renal and nervous systems, causing insulin resistance. Furthermore, it is associated with dyslipidemia and possible hypertension ${ }^{5}$. Its prevalence can reach up to $30 \%$ in those over 65 years of age in certain populations while, in the United States, it is estimated that more than half of diabetic individuals are older adults ${ }^{6}$. Brazil is fourth in the global diabetes ranking, with about 11.9 million cases registered in recent years ${ }^{7}$. The projection for 2025 is that 300 million people will have diabetes worldwide ${ }^{8}$.

DM2 generates a decline in functional capacities and reserves ${ }^{9}$ and frequent hospitalizations, culminating in a tendency of the onset of symptoms that result in the frailty syndrome, demanding more services from the health system ${ }^{10}$.

The association of two chronic conditions makes treatment more difficult due to the sum of their comorbidities. In this sense, the adequate treatment of one condition is not necessarily effective for the other, hindering the desired response. A correct and accurate diagnosis is necessary, since the measurement of these diseases can be carried out in a simple, low-cost and tangible manner in any health system.
Therefore, the aim of the present study was to compare the clinical-functional factors between groups in relation to the frailty syndrome phenotype profile (pre-frail and frail) in older adults with DM2 and, from this, to discover which of these variables most influence the frailty phenotype.

\section{METHOD}

A descriptive, analytical, cross-sectional study with a quantitative approach was performed. Data collection took place at the Laboratory of Technological Innovations in Health, at the Onofre Lopes University Hospital (the Hospital Universitário Onofre Lopes, or HUOL) of the Federal University of Rio Grande do Norte (UFRN), in Natal (Rio Grande do Norte), Brazil. The study took place between February and December 2017, after approval by the Research Ethics Committee under number 1.808.219, and was financed by Universal Public Notice MCTI/CNPq no. 14/2014.

The research participants were taken from the endocrinology and geriatrics sectors of HUOL, at the invitation of the doctors responsible for the sector. Older individuals with a clinical diagnosis of DM2 were indicated to go to the sector to make appointments for evaluation. After the first survey, the evaluation was scheduled on specific days and times and lasted for about $1 \mathrm{~h} 30 \mathrm{~min}$, alternating tests with and without physical effort, so as not to exhaust the individual. The complete evaluation took place on the same day, and was performed by a previously trained evaluator in the presence of the researcher, to provide support for the tests and minimize the risk of falls.

Older individuals aged over 60 years of age, who were diagnosed with DM2 in accordance with the criteria of the American Diabetes Association ${ }^{11}$, whether male or female, who were able to walk independently and who agreed to participate by signing an Informed Consent Term (ICF) were included in the study. Older adults who did not complete the entire assessment were excluded from the study.

To perform the sample calculation, $80 \%$ power and $5 \%$ significance level were used for the two- 
tailed hypothesis tests. Among the variables with the greatest statistical significance for the sample (income, marital status, glycated hemoglobin, use of insulin and MMSE), the largest sample size was for "income", totaling 123 individuals, avoiding possible $\beta$ error in the variables close to significance. In this sense, a sample size of 125 individuals was adopted as it is a multiple of 5 and facilitates the presentation of data.

After sample selection, an interview was conducted with personal, sociodemographic, clinicalfunctional and cognitive screening data, assessment of depressive symptoms, assessment of functional mobility and frailty phenotype.

Personal data were assessed using a semistructured questionnaire containing identification, contact details (cell phone of the older adult or a family member living in the same household, or home phone), date and address. In addition, the sociodemographic data included a list with demarcation of the following items: sex, age, skin color, marital status, education, living arrangement, income, occupation and social participation.

The clinical-functional data were: subjective perception of vision of excellent, very good, good, poor and very poor; height, in meters; weight in kilograms, measured by scale, and Body Mass Index (BMI); number of diseases and medications used, time since diagnosis of DM2, laboratory tests of fasting glycemia and glycated hemoglobin in the last six months (from the date of the evaluation) for the control of DM2; use of antidiabetic drugs and/or insulin; presence of leg pain and intensity, using the Visual Analogue Scale (VAS); falls in the last year.

Cognitive screening was assessed by the MiniMental State Examination (MMSE), which assesses spatial and temporal orientation, immediate memory, ability to calculate, evocation of words with their meanings, repetition, command, reading with interpretation, writing and drawing (graphic ability to reproduce an image). The cut-off points were as follows: illiterate individuals should score $\geq 20$ points; schooling of $1-4$ years $\geq 25$ points; schooling of 5-8 years $\geq 26.5$ points; schooling of 9-11 years $\geq 28$ points and schooling over 11 years $\geq 29$ points $^{12}$.

The Geriatric Depression Scale (GDS) was used in its reduced (or short) version to screen for depressive symptoms. A total of 15 questions were asked with yes or no answers. An individual has depressive symptoms if reaching a score $\geq 5$ points and an "absence of depressive symptoms" in individuals with a score $\leq 4$ points ${ }^{13}$.

Functional mobility was assessed using the Timed Up and Go (TUG) test. This consists of measuring the time spent getting up from a chair, walking 3 meters then returning and sitting with the back completely supported in the chair. Individuals with a time greater than 13.5 seconds have impaired mobility ${ }^{14}$.

In accordance with the frailty phenotype, the following were evaluated:

Unintentional weight loss: it was asked whether the individual had lost $4.5 \mathrm{~kg}$ or more in the year until the date of the assessment and whether this loss was unintentional. If the answers to both questions were positive, 1 point was awarded;

Decrease in handgrip strength assessed by the SH5002 Smedley - Saehaen ${ }^{\circledR}$ Hand Dynamometer. Measured with the individual sitting in a comfortable chair, supporting both feet on the floor and placing their dominant hand on the assessment table, holding the dynamometer grip three times to obtain an average, adjusted according to Table $1^{15}$.

Older adults who measured below the expected value above met the criterion for frailty syndrome, with 1 point.

Decrease in gait speed was calculated through the time spent in seconds to cover 4.6 meters in three tests, to take an average of the value, adjusted by sex and height according to Table $2^{16}$. 
Table 1. Adjustment of sex and BMI for handgrip strength, São Paulo, 2014.

\begin{tabular}{|l|l|l|l|}
\hline \multicolumn{2}{|c|}{ Male } & \multicolumn{2}{c|}{ Female } \\
\hline BMI & Cut off point & BMI & Cut off point \\
\hline $0<$ BMI $\leq 23$ & $\leq 27.00 \mathrm{kgf}$ & $0<\mathrm{BMI} \leq 23$ & $\leq 16.33 \mathrm{kgf}$ \\
\hline $23<\mathrm{BMI}<28$ & $\leq 28.67 \mathrm{kgf}$ & $23<\mathrm{BMI}<28$ & $\leq 16.67 \mathrm{kgf}$ \\
\hline $28 \leq \mathrm{BMI}<30$ & $\leq 29.50 \mathrm{kgf}$ & $28 \leq \mathrm{BMI}<30$ & $\leq 17.33 \mathrm{kgf}$ \\
\hline$\geq 30$ & $\leq 28.67 \mathrm{kgf}$ & $\geq 30$ & $\leq 16.67 \mathrm{kgf}$ \\
\hline
\end{tabular}

Source: Macedo, Freitas and Scheicher, 2014 ${ }^{15}$.

Table 2. Adjustment of weight and sex for gait speed, São Paulo, 2011.

\begin{tabular}{|l|l|l|l|}
\hline \multicolumn{2}{|c|}{ Male } & \multicolumn{2}{c|}{ Female } \\
\hline Weight & Cut off point & Weight & Cut off point \\
\hline $0<$ Weight $\leq 168$ & $\leq 5.49 \mathrm{sec}$ & $0<$ Weight $\leq 155$ & $\leq 6.61 \mathrm{sec}$ \\
\hline Weight $>168$ & $\leq 5.54 \mathrm{sec}$ & Weight $>155$ & $\leq 5.92 \mathrm{sec}$ \\
\hline
\end{tabular}

Source: Costa, Neri, $2011^{16}$.

For exhaustion, the self-reporting of fatigue was carried out through two questions from the Center for Epidemiological Studies - Depression CES-D17: "I felt that I had to make an effort to do my usual tasks" and "I was unable to carry on doing my things". The score was given as (1) never / rarely, (2) a few times, (3) most of the time, (4) always. The older adults who chose options 3 or 4 in any of the questions met the criterion, with 1 point.

Low level of physical activity was assessed by the IPAQ (International Physical Activity Questionnaire) in its short version, adapted from the long version ${ }^{18}$ that allowed the duration of physical activity the older adult performed in the previous week to be estimated. After its application, the older adults were classified as very active, active, irregularly active and sedentary. Those who were classified as irregularly active and sedentary met the criterion with 1 point.

The sum of the positive items generated the classification of the Phenotype of Frailty as follows: frail (3 or more positive items); pre-frail (1 or 2 positive items); not frail (no positive items) ${ }^{19}$.

For data analysis, SPSS software version 20.0 was used and the significance level was set at $5 \%$. For descriptive analysis, a simple case count was performed according to frailty phenotype group. To compare these groups with the sociodemographic, clinical-functional categorical variables, cognitive screening, depressive symptoms and functional mobility, Pearson's chi-square test was used and the intergroup percentages were analyzed.

A multiple logistic regression analysis was performed, using the Stepwise Forward Selection Procedure method with the dichotomous categorical dependent variable "frailty phenotype" with the variables that exhibited statistical significance $(p<0.05)$ in the previously mentioned test. The permanence of the variable in the multiple analysis occurred through the likelihood ratio test (Likelihood Ratio Test), absence of multicollinearity, as well as its ability to improve the model through the HosmerLemeshow test without interfering in the confidence intervals. In all analyzes, a significance level of 5\% was considered.

\section{RESULTS}

In total, 125 older adults participated in this research. However, only 12 of these individuals belonged to the non-frail group (9.6\%) which made the comparison between this group and the others unfeasible due to the limited number of subjects. These individuals were therefore excluded, giving a total sample of 113 older adults. 
The descriptive analysis of the sample is shown in table 3 . The average age was $68.66( \pm 6.62)$ years and the majority were female $(61.9 \%)$, with an average of $6.6( \pm 5.11)$ years of schooling and a level of education considered low, at the level of "illiterate or incomplete elementary I"' (60.2\%).

The inferential analysis of the pre-frail and frail groups with the other study variables is shown in table 4. Significant differences were found between the pre-frail and frail groups for the variables: education $(p=0.004)$, social participation $(p=0.004)$, subjective perception of vision $(p=0.004)$, glycated hemoglobin $(p=0.036)$, pain in lower limbs $(p<0.001)$, falls $(p=0.012)$, depressive symptoms $(p=0.002)$ and mobility by TUGT ( $p=0.004)$. These variables were designed as a binary logistic regression model.

For the logistic regression analysis (Stepwise Forward Selection Procedure method), the variables schooling, glycated hemoglobin, pain in lower limbs and TUGT remained until the end of the model, as shown in table 5 . The model showed an accuracy of $93.6 \%$.

Table 3. Descriptive analysis of sociodemographic, clinical-functional, cognitive screening, depressive symptoms, functional mobility and frailty phenotype data. Natal, Rio Grande do Norte, 2018.

\begin{tabular}{|c|c|}
\hline Characteristic (n) & $\mathrm{n}(\%)$ \\
\hline \multicolumn{2}{|l|}{$\operatorname{Sex}(n=113)$} \\
\hline Male & $43(38.1 \%)$ \\
\hline Female & $70(61.9 \%)$ \\
\hline \multicolumn{2}{|l|}{ Age group in years $(n=113)$} \\
\hline $60-69$ & $70(61.9 \%)$ \\
\hline 70 or more & $43(38.1 \%)$ \\
\hline \multicolumn{2}{|l|}{ Married $(\mathrm{n}=113)$} \\
\hline Married & $40(35.4 \%)$ \\
\hline Unmarried & $73(64.6 \%)$ \\
\hline \multicolumn{2}{|l|}{ Schooling $(n=113)$} \\
\hline Illiterate or incomplete elementary I & $68(60.2 \%)$ \\
\hline Complete Elementary or Post-Elementary I & $45(39.8 \%)$ \\
\hline \multicolumn{2}{|l|}{ Income (minimum wage) $(\mathrm{n}=113)$} \\
\hline Up to two & $62(54.9 \%)$ \\
\hline Three or more & $51(45.1 \%)$ \\
\hline \multicolumn{2}{|l|}{ Social participation $(\mathrm{n}=113)$} \\
\hline Participates in community activities & $64(56.6 \%)$ \\
\hline Does not participate in community activities & $49(43.4 \%)$ \\
\hline \multicolumn{2}{|l|}{ Subjective perception of vision $(\mathrm{n}=113)$} \\
\hline Excellent, very good or good & $60(53.1 \%)$ \\
\hline Poor or very poor & $53(46.9 \%)$ \\
\hline \multicolumn{2}{|l|}{ Body Mass Index (n=113) } \\
\hline Malnourished or normal weight & $44(38.9 \%)$ \\
\hline Overweight & $69(61.1 \%)$ \\
\hline \multicolumn{2}{|l|}{ Number of diseases $(n=113)$} \\
\hline 1 to 4 & $39(34.5 \%)$ \\
\hline 5 or more & $74(65.5 \%)$ \\
\hline \multicolumn{2}{|l|}{ Number of medicines $(n=110)$} \\
\hline 1 to 4 & $42(38.2 \%)$ \\
\hline 5 or more & $68(61.8 \%)$ \\
\hline
\end{tabular}


Continuation of Table 3

Time since diagnosed with DM2 in years $(n=108)$

0 to 5

6 or more

$63(58.3 \%)$

Glycated hemoglobin ( $\mathrm{n}=81)$

Up to $8 \%$ (normal)

$43(53.1 \%)$

Above $8,1 \%$ (altered)

$38(46.9 \%)$

Fasting blood glucose $(\mathrm{n}=108)$

Up to $130 \mathrm{mg} / \mathrm{dL}$ (normal)

$55(50.9 \%)$

$131 \mathrm{mg} / \mathrm{dL}$ or more (altered)

$53(49.1 \%)$

Use of insulin $(\mathrm{n}=113)$

Yes

$33(29.2 \%)$

No

$80(70.8 \%)$

Pain in lower limbs $(\mathrm{n}=113)$

Yes

$61(54.0 \%)$

No

$52(46.0 \%)$

Falls in the last year $(\mathrm{n}=113)$

No

Yes

$41(36.3 \%)$

Mini Mental State Examination $(\mathrm{n}=113)$

Cognitive deficit

$46(40.7 \%)$

No cognitive deficit

$67(59.3 \%)$

Geriatric Depression Scale ( $\mathrm{n}=113$ )

Depressive Symptoms

$65(57.5 \%)$

No Depressive Symptoms

$48(42.5 \%)$

Timed Up and Go Test ( $\mathrm{n}=106)$

Low risk of falls

$86(81.1 \%)$

High risk of falls

$20(18.9 \%)$

Unintentional weight loss

Yes

$21(18.6 \%)$

No

$92(81.4 \%)$

Decreased handgrip strength

Yes

No

$60(53.1 \%)$

Exhaustion

Yes

$69(61.1 \%)$

No

$44(38.9 \%)$

Low level of physical activity

Yes

$90(79.6 \%)$

No

$23(20.4 \%)$

Decrease in walking speed

Yes

$53(46.9 \%)$

No

$60(53.1 \%)$

Source: author. 
Table 4. Chi-square test between the frailty phenotype (pre-frail and frail) and the sociodemographic and clinicalfunctional variables of the sample. Natal, 2018.

\begin{tabular}{|c|c|c|c|}
\hline Variable & Pre-frail & Frail & $p$-value \\
\hline \multicolumn{4}{|l|}{ Sex } \\
\hline Male & $23(20.4 \%)$ & $20(17.7 \%)$ & 0.831 \\
\hline Female & $36(31.9 \%)$ & $34(30.1 \%)$ & \\
\hline \multicolumn{4}{|l|}{ Age group in years } \\
\hline $60-69$ & $41(36.6 \%)$ & $29(25.7 \%)$ & 0.084 \\
\hline 70 or more & $18(15.9 \%)$ & $25(22.1 \%)$ & \\
\hline \multicolumn{4}{|l|}{ Married } \\
\hline Married & $18(15.9 \%)$ & $22(19.5 \%)$ & 0.256 \\
\hline Unmarried & $41(36.3 \%)$ & $32(28.3 \%)$ & \\
\hline \multicolumn{4}{|l|}{ Schooling } \\
\hline Illiterate or fund. Incomplete I & $28(24.8 \%)$ & $40(35.4 \%)$ & $0.004^{*}$ \\
\hline Fund I complete or post fund I & $31(27.4 \%)$ & $14(12.4 \%)$ & \\
\hline \multicolumn{4}{|l|}{ Income (minimum wage) } \\
\hline Up to two & $28(24.8 \%)$ & $34(30.1 \%)$ & 0.098 \\
\hline Above three & $31(27.4 \%)$ & $20(17.7 \%)$ & \\
\hline \multicolumn{4}{|l|}{ Social participation } \\
\hline Yes & $41(36.3 \%)$ & $23(20.4 \%)$ & $0.004^{*}$ \\
\hline No & $18(15.9 \%)$ & $31(27.4 \%)$ & \\
\hline \multicolumn{4}{|l|}{ Subjective perception of vision } \\
\hline Excellent, very good or good & $39(34.5 \%)$ & $21(18.6 \%)$ & $0.004^{*}$ \\
\hline Poor or very poor & $20(17.7 \%)$ & $33(29.2 \%)$ & \\
\hline \multicolumn{4}{|l|}{ Body Mass Index } \\
\hline Malnourished or normal weight & $27(23.9 \%)$ & $17(15.0 \%)$ & 0.120 \\
\hline Overweight & $32(28.3 \%)$ & $37(32.7 \%)$ & \\
\hline \multicolumn{4}{|l|}{$\mathrm{N}^{\circ}$ of diseases } \\
\hline 1 to 4 & $22(19.5 \%)$ & $17(15.0 \%)$ & 0.517 \\
\hline 5 or more & $37(32.7 \%)$ & $37(32.7 \%)$ & \\
\hline \multicolumn{4}{|l|}{$\mathrm{N}^{\circ}$ of medicines } \\
\hline 1 to 4 & $23(20.9 \%)$ & $19(17.3 \%)$ & 0.525 \\
\hline 5 or more & $33(30.0 \%)$ & $35(31.8 \%)$ & \\
\hline \multicolumn{4}{|l|}{ Time since diagnosis } \\
\hline 0 to 5 years & $26(24.1 \%)$ & $19(17.6 \%)$ & 0.229 \\
\hline 6 years or more & $29(26.9 \%)$ & $34(31.5 \%)$ & \\
\hline \multicolumn{4}{|l|}{ Glycated hemoglobin } \\
\hline Normal (up to $8 \%$ ) & $27(33.3 \%)$ & $16(19.8 \%)$ & $0.036^{*}$ \\
\hline Altered $(8,1 \%$ or more $)$ & $15(18.5 \%)$ & $23(28.4 \%)$ & \\
\hline \multicolumn{4}{|l|}{ Fasting blood glucose } \\
\hline Normal (0-130) & $34(31.5 \%)$ & $21(19.4 \%)$ & 0.085 \\
\hline Altered (131 or more) & $24(22.5 \%)$ & $29(26.9 \%)$ & \\
\hline \multicolumn{4}{|l|}{ Use of Insulin } \\
\hline Yes & $14(12.4 \%)$ & $19(16.8 \%)$ & 0.181 \\
\hline No & $45(39.8 \%)$ & $35(31.0 \%)$ & \\
\hline
\end{tabular}


Continuation of Table 4

\begin{tabular}{llll}
\hline Variable & Pre-frail & Frail & $p$-value \\
\hline Pain in lower limbs & & & \\
Yes & $21(18.6 \%)$ & $40(35.4 \%)$ & $<0.001^{*}$ \\
No & $38(33.6 \%)$ & $14(12.4 \%)$ & \\
\hline Falls in the last year & & & \\
Yes & $15(13.3 \%)$ & $26(23.0 \%)$ & $0.012^{*}$ \\
No & $44(38.9 \%)$ & $28(24.8 \%)$ & \\
Mini Mental State Examination & & & \\
Cognitive deficit & $24(21.2 \%)$ & $32(19.5 \%)$ & 0.995 \\
No cognitive deficit & $35(31.0 \%)$ & $39(34.5 \%)$ & \\
Geriatric Depression Scale & & $15(13.3 \%)$ & \\
Depressive symptoms & $26(23.0 \%)$ & & \\
Normal & $33(29.2 \%)$ & $34(32.1 \%)$ & $0.002^{*}$ \\
Timed Up and Go Test & & $15(14.2 \%)$ & \\
Lower risk of falling & $52(49.1 \%)$ & & \\
Higher risk of falling & $05(04.7 \%)$ & & \\
\hline
\end{tabular}

*Statistical significance $(p \leq 0,05)$; Test used: chi-square.

Source: author.

Table 5. Binary logistic regression with variables that showed statistical significance with the frailty phenotype. Natal, 2018.

\begin{tabular}{lllll}
\hline Variable & PR & PR adjusted & P & CI (95\%) \\
\hline Schooling & 1.89 & 1.91 & 0.039 & $1.03-3.52$ \\
\hline Pain in lower limbs & 2.44 & 2.10 & 0.025 & $1.10-4.03$ \\
\hline Risk of falls & 0.53 & 0.38 & 0.033 & $0.16-0.93$ \\
\hline
\end{tabular}

PR: prevalence ratio; CI: confidence interval.

Source: author.

\section{DISCUSSION}

The finding of a majority of women (61.9\%) was similar to the study by Silva, Pureza and Landre ${ }^{10}$, in which $70.0 \%$ of the sample of older adults evaluated at the outpatient clinic were female.

The majority $(60.2 \%)$ of the sample had a level of schooling of illiterate or incomplete elementary education I, data which is similar to the study by Ribeiro et al. ${ }^{20}$, in which in the majority of a sample of 60 older diabetics participating in an outpatient center in Minas Gerais (59.58\%) were also classified as having a low level of education. The lack of access to education for this population can therefore be highlighted. This value is notable due to the strong impact that schooling has on the frailty phenotype. From the regression model shown above, illiterate pre-frail diabetic older adults or those with incomplete elementary education I have a 1.91 times higher prevalence of becoming frail than those with complete elementary or post-elementary education I.

As education is an indicator of the socioeconomic conditions of a population, it is essential that it is discussed and contrasted, as in the case of the study by Beltrame ${ }^{21}$, with a sample of 50 diabetic and 50 non-diabetic older adults, in which $84.0 \%$ were literate. This average is well above that of the present study, but it is worth mentioning that the municipal region studied (Concórdia, Santa Catarina) has one of the highest Human Development Indexes in Brazil, unlike Natal (Rio Grande do Norte), a city in one of the least developed regions of the country. 
The average income of the sample in question was $\mathrm{R} \$ 2.367 .74$ ( $\pm 1.385 .90)$. In a cohort study conducted with 202 older community members in Lafaiete Coutinho (Bahia), the sample's per capita income was less than one minimum wage ${ }^{22}$. A study in a hospital environment includes older people who are, at least, able to walk and eat on consultation days; a study with community-dwelling older people, on the other hand, may include low-income older people as there is no need for mobility on their part.

Most of the sample was overweight, with an average BMI value of $28.58( \pm 4.45)$. This data is confirmed when an analysis of the sedentary lifestyle of the sample in this study is made. Among the respondents, $79.6 \%$ of the older adults claimed they did not perform any type of physical activity, highlighting the absence of one of the most controlling factors of the metabolic indexes. Another study, carried out in Campinas (Sao Paulo) with older community members, showed that $54.73 \%$ of 689 older people were sedentary ${ }^{16}$.

Although visual problems are common in a diabetic population, the majority of the sample classified their vision as excellent, very good or good $(53.1 \%)$. The impact of visual impairment on diabetics may even involve self-administration of medication. Harada and Schor ${ }^{23}$ described the medication problems of older diabetics with blindness or low vision, and the reported problems were diverse, such as errors in quantity, lack of perception of which medication they are taking and even problems receiving the medication, while not knowing which one is correct. Almeida et al. ${ }^{24}$ also reported that impaired vision makes adherence to adequate treatment difficult and provides an effect of marked blood hyperglycemia.

Another worrying fact was the number of diseases present in the sample, as the majority had five or more illnesses $(65.5 \%)$, showing the overlap of NCDs and the need for effective care with this sample group. This fact could also be expected by the sample profile, as it is taken from a reference hospital with several modalities of care. According to Confortin et al. ${ }^{25}$, the overlap of chronic diseases directly implies the loss of manual muscle strength and even quality of life as a final outcome. Still, Silva et al. ${ }^{26}$, in their study with 1391 older people registered in the Family Health Strategy in Rio Grande do Sul, showed that the association of chronic diseases is directly linked to depression, a fact that was also investigated in the present study.

The sample showed uncontrolled mean values of the indices that permeate DM2, for example, the mean glycated hemoglobin in the sample was $8.26 \%$ $( \pm 2.49)$ and the mean fasting blood glucose was $156.32 \mathrm{mg} / \mathrm{dL}$, both of which were above the average expected for older adults. Most of the older people in question were sedentary, and it is known that a sedentary lifestyle is a favorable condition for the lack of glycemic control. The mean fasting glycemia and glycated hemoglobin in this study were higher than those in the study by Heubel et al. ${ }^{27}$ in which the older adults were treated by the Physiotherapy Clinic at the Sagrado Coração University, in Buaru (Sao Paulo). In the aforementioned study, the mean fasting blood glucose was $126.3 \mathrm{mg} / \mathrm{dL}$ and the glycated hemoglobin was $7.2 \%$. This contrasting difference can be justified by the regular practice of physical activity by the older adults in the study mentioned.

Insulin therapy is essential for when there is a partial or total decrease in insulin by the body itself. In this sense, insulin is administered in advanced and more severe cases of the disease $\mathrm{e}^{28}$. In the present study, the majority of the sample did not use insulin $(70.8 \%)$. As the older adults in the study were already in outpatient care and were referred by the professionals who care for them, it is understandable that the vast majority do not use insulin because they may already have the disease in a controlled manner.

More than half of the sample (54.0\%) reported pain in their lower limbs, which is a very important factor in predicting falls and functional mobility. This variable remained in the regression model, in order to infer that pre-frail diabetic older people with lower limb pain have a 2.10 times higher prevalence of becoming frail than those who do not have lower limb pain.

Pain generates discomfort, limits the quality of life of the older adults in general, implies an increased dependence on the use of medications to control it, decreases energy and generates fatigue, hinders sleep and rest for the diabetic older and worsens 
performance at work ${ }^{21}$. Based on this, pain was the characteristic most related to the presence of DM2 in the study mentioned and may be directly related to diabetic neuropathy.

Linked to this, 41 older (36.3\%) reported one or more falls in the last year. This data raises a serious concern as the consequences of falls may be due to fear of falling and death. Groups with greater susceptibility, such as those with diabetes, have more dangerous consequences ${ }^{29}$.

According to the MMSE analysis, the majority of the sample $(59.3 \%)$ did not show cognitive decline, with an average of $23.79( \pm 4.22)$ points. This data contrasts with current literature, which has already verified the association between diabetes mellitus and the presence of cognitive decline ${ }^{30,31}$.

The service linked to the sample covers several medical areas in the state reference hospital. As these older people already have specialized medical care, another variable may also have been an influence, which was mobility. Most of the sample did not show any change in mobility (81.1\%), analyzed using the TUGT. It is important to understand that the mobility data do not specify whether the older adults have any other associated comorbidity, which may generate certain incorrect implications of the study ${ }^{14}$.

Mobility was a strong variable for the present study, since, from the regression model, pre-frail diabetic older people who have less impairment of mobility assessed by the TUGT have 38\% more chances of not becoming frail. This high percentage suggests that functional mobility is directly linked to the frailty syndrome. Therefore, as the loss of strength is a predictor of the frailty syndrome, older adults who lose strength may become frail and will have functional mobility problems ${ }^{32}$.

The GDS identified that the predominance of the sample had depressive symptoms (57.5\%). Some national studies reveal the high prevalence of depressive symptoms in older people with DM2. Exemplifying this finding, Moreira et al. ${ }^{33}$ identified the high prevalence of depressive symptoms and reduced quality of life in a study with older diabetics. In this sense, the presence of DM2 in the older adults generates dissatisfaction with life, decreased mobility and social isolation, factors closely related to depressive symptoms.

Based on the phenotype indexes, the low level of physical activity measured by IPAQ was the most evident, affecting $79.6 \%$ of the studied population. Unintentional weight loss was the least mentioned, affecting only $18.6 \%$ of the sample. These data demonstrate important characteristics as sarcopenia is a potential predictor of FS in older adults and is a common characteristic in patients with DM2, in other words, there is a direct link between these two conditions ${ }^{34}$.

An older adult with less muscle mass will also have a tendency to maintain poorer blood glucose control. This characteristic occurs due to the difficulty in capturing muscle glucose. In this sense, insulin will be secreted inefficiently and insulin resistance may be one of the outcomes, implying a characteristic condition of DM2?.

The presence of DM2 can contribute to creating an environment conducive to DES as its characteristics increase the incidence of frailty components. In this sense, weakness, exhaustion, slowness, weight loss, physical inactivity and even other comorbidities, such as cognitive deficit, are related ${ }^{6}$.

In relation to the pre-frail group, there was a higher occurrence of women, aged between 60-69 years, who were married, had a complete elementary I or post-elementary I education, an income above three minimum wages, who participated in community activities, had a subjective perception of vision of excellent, very good or good, who were overweight, had five or more diseases, took five or more medications, had normal glycated hemoglobin, normal blood glucose, did not use insulin, had no pain in the lower limbs, had not fallen in the previous year, did not have cognitive deficit according to the MMSE, , experienced less change in mobility according to the TUGT, had no unintentional weight loss, no loss of strength, no exhaustion, a low level of physical activity and no decrease in gait speed.

In relation to the frail group, the prevalence was similar to the pre-frail group, except for the 
prevalence of illiteracy or an incomplete elementary education, an income of up to two minimum wages, no participation in community activities, a perception of their vision as poor or very poor, altered glycated hemoglobin and fasting glucose, with lower limb pain and depressive symptoms.

While it is not possible to elaborate a cause and effect analysis due to the methodological approach of the study, it is known that these data are related. This relationship allows the creation of specific research on the theme which addresses the causal meaning of these factors to serve as a basis for future therapies. It is therefore inferred that the limitations of the lives of diabetic older adults that make them frail permeate social factors relating to the context in which they are inserted together with their clinical conditions. Longitudinal studies are also suggested in order to verify causality among the variables studied.

The limitations of the present study were related to the scarcity of works in literature that compare the frailty syndrome in older adults with the presence of DM2. Perhaps, because it is the sum of two chronic diseases with high morbidity, these data rarely appear in Brazilian literature. In addition, the recruitment of older adults and the difficulty in accessing the HUOL were limiting factors for carrying out the assessment.

\section{CONCLUSIONS}

In terms of the clinical-functional factors related to the frailty phenotype profile, the variables education, social participation, subjective perception of vision, glycated hemoglobin, pain in the lower limbs, falls in the previous year, depressive symptoms and risk of falls were those that presented statistical difference between the groups studied. Among all the variables, schooling, pain in the lower limbs and risk of falls were those most related to the worsening of the syndrome and its progress.

These data show the characteristics that can be further focused on in rehabilitation and care/ management programs with older diabetics. All these findings reinforce the need to explain the common characteristics of DM2 and the Frailty Syndrome, strengthening geriatrics and gerontology at all levels.

Edited by: Ana Carolina Lima Cavaletti

\section{REFERENCES}

1. Fhon JRS, Rodrigues RAP, Santos JLF, Diniz MA, Santos EB, Almeida VC, et al. Factors associated with frailty in older adults: a longitudinal study. Rev Saúde Pública [Internet]. 2018 [acesso em 10 mar. 2020];52:1-8. Disponível em: https://www.scielosp. org/article/rsp/2018.v52/74/en/

2. Marty E, Liu Y, Samuel A, Or O, Lane J. A review of sarcopenia: enhancing awareness of an increasingly prevalent disease. Bone [Internet]. 2017 [acesso em 12 ago. 2019];105:276-86. Disponível em: https://www.sciencedirect.com/ science/article/pii/S8756328217303459?casa_ token $=\mathrm{XrLmYcPdclkAAAAA:B-}$ RRoMo_sWvHbP2-XHD-F_PuljA_ Ak2nFQ8xxDBS3ENaPnngT-wAtan0yXziFd36VnM8m9r0gs
3. Freitas CV, Sarges ESNF, Moreira KECS, Carneiro SR. Evaluation of frailty, functional capacity and quality of life of the elderly in geriatric outpatient clinic of a university hospital. Rev Bras Geriatr Gerontol [Internet].2016 [acesso em 12 ago. 2019 ];19(1):119-28. Disponível em: http://www.scielo.br/scielo.php?pid=S180998232016000100119\&script=sci_arttext\&tlng=pt

4. Yanase Y, Yanagita I, Muta K, Nawata H. Frailty in elderly diabetes patients. Endocr J [Internet]. 2017[acesso em 12 ago. 2019];65:1-11. Disponível em: https://www.jstage.jst.go.jp/article/endocrj/ advpub/0/advpub_EJ17-0390/_article/-char/ja/

5. Sociedade Brasileira de Diabetes. Diretrizes da Sociedade Brasileira de Diabetes 2017-2018 [Internet]. de Oliveira JEP, Montenegro Junior RM, Vencio Sérgio, organizadores. São Paulo: Editora Clannad; 2017 [acesso em 12 ago. 2019]. Disponível em: https://www.diabetes.org.br/profissionais/ images/2017/diretrizes/diretrizes-sbd-2017-2018.pdf 
6. Sinclair AJ, Rodriguez-Manas L. Diabetes and frailty: two converging conditions? Can J Diabetes [Internet]. 2016 [acesso em 12 ago. 2019];40(1):7783. Disponível em: https://www.sciencedirect. com/science/article/pii/S1499267115006322?casa_ token=BffMdnUar3sAAAAA:fFz-O_ wOjOBjg4vHfp0BBA-H-O0f0herOYTVgqOKipDu YnHP2gOnybGHF94DB4LJWFn4Jmss4NU

7. Costa AF, Flor LS, Campos MR, Oliveira AF, Costa MFS, Silva RS, et al. Carga do diabetes mellitus tipo 2 no Brasil. Cad Saúde Pública [Internet]. 2017 [acesso em 12 ago. 2019];33(2): e00197915 [14 p.]. Disponível em: https://www.scielosp.org/article/csp/2017.v33n2/ e00197915/

8. Wild S, Roglic G, Green A, Sicree R, King H. Global prevalence of diabetes: estimates for the year 2000 and projections for 2030. Diabetes Care [Internet.]2004 [acesso em 12 ago 2019];27(5):1047-53. Disponível em: https://care.diabetesjournals.org/content/27/5/1047

9. Perkisas S, Vandewoude M. Where frailty meets diabetes. Diabetes Metab Res Rev [Internet]. 2016 [acesso em 12 ago. 2019];32(Supp 1):261-7. Disponível em: https://onlinelibrary.wiley.com/doi/full/10.1002/ dmrr.2743

10. Silva AP, Pureza DY, Landre CB. Frailty syndrome in elderly patients with type 2 diabetes mellitus. Acta Paul Enferm [Internet]. 2015 [acesso em 12 ago. 2019];28(6):503-9. Disponível em: http://www.scielo.br/scielo.php?pid=S0103$21002015000600503 \&$ script $=$ sci_arttext\&tlng=pt

11. American Diabetes Association: Classification and Diagnosis of Diabetes. Diabetes Care [Internet]. 2017 [acesso em 12 ago. 2019];40:11-24. Disponível em: https://care.diabetesjournals.org/content/38/ Supplement_1/S8

12. Brucki SMD, Nitrini R, Caramelli P, Bertolucci PHF, Okamoto IH. Sugestões para o uso do mini-exame do estado mental no Brasil. Arq Neuropsiquiatr [Internet]. 2003 [acesso em 12 ago. 2019];61(3b):777-81. Disponível em: http://www.scielo.br/scielo.php?pid=S0004282X2003000500014\&script=sci_arttext

13. Paradela EMP, Lourenço RA, Veras RP. Validation of geriatric depression scale in a general outpatient clinic. Rev Saúde Pública [Internet]. 2005 [acesso em 12 ago. 2019];39(6):918-23. Disponível em: https://www. scielosp.org/article/rsp/2005.v39n6/918-923/en/

14. Aveiro MC, Driusso P, Barham EJ, Pavarini SCI, Oish J. Mobilidade e risco de quedas de população idosa da comunidade de São Carlos. Ciênc Saúde Coletiva. 2012 [acesso em 12 ago. 2019];17(9):2481-88. Disponível em: http://www.scielo.br/scielo.php?pid=S1413$81232012000900028 \&$ script $=$ sci_arttext
15. Macedo DO, Freitas LM, Scheicher ME. Handgrip and functional mobility in elderly with different levels of physical activity. Fisioter Pesqui [Internet]. 2014 [acesso em 12 ago. 2019];21(2):151-5. Disponível em: http://www.scielo.br/scielo.php?pid=S180929502014000200151\&script=sci_arttext

16. Costa TB, Neri AL. Medidas de atividade física e fragilidade em idosos: dados do FIBRA Campinas, São Paulo, Brasil. Cad Saúde Pública [Internet]. 2011 [acesso em 12 ago. 2019];27(8):1537-50. Disponível em: http://www.scielo.br/scielo.php?pid=S0102311X2011000800009\&script=sci_arttext

17. Batistoni SST, Neri AL, Cupertino APFB. Validity of the Center for Epidemiological Studies Depression Scale (CES-D) among Brazilian elderly. Rev Saúde Pública [Internet]. 2007 [acesso em 12 ago. 2019];41:598-605. Disponível em: https://www. scielosp.org/article/rsp/2007.v41n4/598-605/en/

18. Hagströmer M, Oja P, Sjöström M. The International Physical Activity Questionnaire (IPAQ): a study of concurrent and construct validity. Public Health Nutr [Internet]. 2006 [acesso em 12 ago. 2019];9(6):75562. Disponível em: https://www.cambridge.org/ core/journals/public-health-nutrition/article/ international-physical-activity-questionnaire-ipaqa-study-of-concurrent-and-construct-validity/ A78914A4CFE41987A40C122FDF8BE229

19. Fried LP, Tangen CM, Walston J, Newman AB, Hirsch C, Gottdiener J, et al. Frailty in Older Adults: Evidence of a Phenotype. J Gerontol Ser A Biol Sci Med Sci [Internet]. 2001 [acesso em 12 ago. 2019];56(3):146-56. Disponível em: https:// academic.oup.com/biomedgerontology/article/56/3/ M146/545770

20. Ribeiro WFP, Carvalho MRF, Moura AP, Cássia TC. Conhecendo o grau de risco para o desenvolvimento do pé diabético em pessoas idosas com diabetes mellitus tipo 2. Enferm Brasil [Internet]. 2017 [acesso em 12 ago. 2019];16(2):80-8. Disponível em: http://portalatlanticaeditora.com.br/index.php/ enfermagembrasil/article/view/995

21. Beltrame V. Qualidade de vida de idosos diabéticos [tese na Internet]. Porto Alegre: Pontifícia Universidade Católica do Rio Grande do Sul; 2008 [acesso em 12 ago. 2019]. Disponível em: http://tede2. pucrs.br/tede2/handle/tede/2581

22. Matos FS, Jesus CS, Carneiro JAO, Coqueiro RS, Fernandes MH, Brito TA. Redução da capacidade funcional de idosos residentes em comunidade: estudo longitudinal. Ciênc Saúde Colet [Internet]. 2018 [acesso em 10 mar. 2020];23(10):3393-3401. Disponível em: https://www.scielosp.org/article/ csc/2018.v23n10/3393-3401/pt/ 
23. Harada FJB, Schor P. O problema da autoadministração de medicamentos por idosos com baixa visão e cegueira sob a ótica do design centrado no humano. Blucher Design Proceedings [Internet]. 2016 [acesso em 12 ago. 2019];2(9):126779. Disponível em: http://pdf.blucher.com.br/ designproceedings/ped2016/0108.pdf

24. Almeida A, Oliveira H, Pimentel L, Mendonça MC, Santos M. Hiperglicemia crônica e o seu comprometimento na visão. Cad Med UNIFESO [Internet]. 2019 [acesso em 10 mar. 2020];2(2):13442. Disponível em: http://www.revista.unifeso.edu. br/index.php/cadernosdemedicinaunifeso/article/ view/1399/600

25. Confortin SC, Danielewicz AL, Antes DL, Ono LM, D’Orsi E, Barbosa AR. Associação entre doenças crônicas e força de preensão manual de idosos residentes em Florianópolis-SC, Brasil. Ciênc Saúde Colet [Internet]. 2018 [acesso em 10 mar. 2020];23(5):1675-85. Disponível em: https://www. scielosp.org/article/csc/2018.v23n5/1675-1685/pt/

26. Silva AR, Sgnaolin V, Nogueira EL, Loureiro F, Engroff P, Gomes I. Doenças crônicas não transmissíveis e fatores sociodemográficos associados a sintomas de depressão em idosos. J Bras Psiquiatr [Internet]. 2017 [acesso em 10 mar. 2020];66(1):4551. Disponível em: http://www.scielo.br/scielo. php?pid=S0047-20852017000100045\&script $=$ sci_ abstract\&tlng=pt

27. Heubel AD, Gimenes C, Marques TS, Arca EA, Martinelli B, Barrile SR. Treinamento multicomponente melhora a aptidão funcional e controle glicêmico de idosos com diabetes tipo 2. J Phys Educ [Internet]. 2018 [acesso em 10 mar. 2020];29(1):1-9. Disponível em: http://186.233.154.236/ojs/index.php/RevEducFis/ article/view/32996/21933

28. Almeida DA, Santos MS, Rosa WAG, Zeferino MGM, Oliveira ISB, Lenza NFB. Conhecimento dos cuidadores intradomiciliares de idosos com DM tipo 2 em insulinoterapia, na atenção primária. Saúde (Santa Maria) [Internet.] 2018 [acesso em 10 mar. 2020];44(2):1-13. Disponível em: https://periodicos. ufsm.br/revistasaude/article/view/31014
29. Vieira LS, Gomes AP, Bierhals IO, Farías-Antúnez S, Ribeiro CG, Miranda VIA, et al. Quedas em idosos no Sul do Brasil: prevalência e determinantes. Rev Saúde Pública [Internet]. 2018 [acesso em 10 mar. 2020];52:1-13. Disponível em: https://www.scielosp. org/article/rsp/2018.v52/22/pt/

30. Ferreira MC, Tozatti J, Fachin SM, Oliveira PP, Santos RF, Silva MER. Reduction of functional mobility and cognitive capacity in type 2 diabetes mellitus. Arq Bras Endocrinol Metab [Internet]. 2014 [acesso em 12 ago. 2019];58(9):946-52. Disponível em: http://observatorio.fm.usp.br/handle/OPI/9598

31. Vargas LS, Lara MVS, Mello-Carpes PB. Influence of diabetes and physical exercise, mental and recreational activities practice on the cognitive function and emotionality in aging groups. Rev Bras Geriatr Gerontol [Internet]. 2014 [acesso em 12 ago. 2019];17(4):867-78. Disponível em: http://www.scielo.br/scielo.php?pid=\$180998232014000400867\&script $=$ sci_arttext\&tlng=pt

32. Soares AV, Marcelino E, Maia KC, Borges Júnior NG. Relação entre mobilidade funcional e dinapenia em idosos com fragilidade. [Internet]. 2017 [acesso em 10 mar. 2020];15(3):278-82. Disponível em: http://www.scielo.br/scielo.php?pid=S167945082017000300278\&script $=$ sci_arttext\&tlng=pt

33. Moreira RO, Amâncio APRL, Brum HR, Vasconcelos DL, Nascimento GF. Depressive symptoms and quality of life in type 2 diabetic patients with diabetic distal polyneuropathy. Arq Bras Endocrinol Metab [Internet]. 2009 [acesso em 12 ago. 2019];53(9):110311. Disponível em: https://europepmc.org/article/ med/20126868

34. Cleasby ME, Jamieson PM, Atherton PJ. Insulin resistance and sarcopenia: mechanistic links between common co-morbidities. J Endocrinol [Internet]. 2016 [acesso em 10 mar. 2020];229(2):67-81. Disponível em: http://www.research.ed.ac.uk/portal/files/24385316/ Cleasby_et_al_Review_JoE.pdf 